\title{
Study on Correlation Between Hotel Cleaners' Musculoskeletal Pain and Cleaning Pose by RULA (Upper Limb Assessment) and MSDs Checklist: Using Hot Spring Hotels and Motels in Taiwan as Examples
}

\author{
Jun-Yuan Kuo ${ }^{1}$, Yun-Chin Chen ${ }^{2, *}$, Chih-Yong $\mathrm{Chen}^{3}$ and Li-Wen $\mathrm{Liu}^{3}$ \\ ${ }^{I}$ Department of International Business, Kainan University, Kainan Road, Taoyuan, 33857, ROC Taiwan; ${ }^{2}$ Department \\ of Business Administration, De Lin Institute of Technology, Qingyun Road, New Taipei City, 23654, ROC Taiwan; \\ ${ }^{3}$ Institute of Occupational Safety and Health, Council of Labor Affairs, Executive Yuen, Hengke Road, New Taipei City, \\ 22143, ROC Taiwan
}

\begin{abstract}
Information of hotel cleaners' musculoskeletal pain can be acquired by subjective survey on patients. The ultrasonic waves and X-ray examination can reveal the parts of muscular trauma, bones and joints, and fracture. Medical instruments can recognize the situation musculoskeletal pain and related treatment and recovery will be offered. However, after pain is relieved, hotel cleaners often experience musculoskeletal pain again. Hot Spring Hotels and Motels in employment caused by the cleaners will reduce the manpower supply shortage, the impact of manpower supply chain management (SCM) performance.Hence, it is necessary to find the causes of their musculoskeletal pain. Does cleaning pose cause hotel cleaners' musculoskeletal pain? It is an important research topic. Hence, this study probed into the correlation among hotel cleaners' working pose, force and musculoskeletal pain by RULA (Upper Limb Assessment). The MSDs Checklist revealed the risk factors of cleaning as the reference for medical personnel's diagnosis and treatment. This study treated hot spring hotel and motel cleaners as the subjects. According to the results, based on the correlation between hotel cleaners' musculoskeletal discomfort and RULA, subjective discomfort of neck, body and upper arm is significantly related to score of RULA. A comparison of hot spring hotel and motel cleaners' work situations showed that when cleaning hot spring pools and bathtubs, the scores of different poses in RULA vary significantly. This is due to different designs of hot spring pools of hot spring hotels and Jacuzzis of motels. The cleaners may easily have musculoskeletal discomfort due to excessive force and bad poses. This study suggests using long brushes to improve bad poses and excessive force. According to the analytical result of MSDs, regarding raising mattress and changing bed sheet and bedspread, compared to hot spring hotels, motels are more dangerous. Regarding cleaning of bathtubs and hot spring pools, hot spring hotels are more dangerous than motels. The findings of this study can serve as reference for hotels to improve work process or for medical personnel to enhance diagnosis and treatment.
\end{abstract}

Keywords: Hot spring hotel and motel cleaners, MSDs checklist, musculoskeletal pain, rapid upper limb assessment (RULA), supply chain management (SCM).

\section{INTRODUCTION}

Tourists are increasing year by year in Taiwan. Hotel cleaners have heavy and frequent works, and tend to encounter musculoskeletal pain. After they receive medical treatment, and the pain is relieved, with heavy and highly repetitive works, they experience musculoskeletal pain again. Does cleaning pose cause hotel cleaners' musculoskeletal pain? It is an important research topic.

Regarding the research on hotel cleaners' musculoskeletal pain, many scholars have proposed the views. Krause et al. [1] investigated room cleaners of hotels in U.S. According to the research, $63 \%$ suggested that they had low back discomfort. $43 \%$ had neck discomfort and $59 \%$ had upper limb discomfort.
NIOSH [2] assessed work process of room cleaners in hotels of the U.S. and developed the statistical result of different studies, such as low back, shoulders and neck and upper limb discomfort.

Frumin et al. [3] conducted questionnaire survey on 3564 room cleaners of 87 unions of hotel industry in the U.S. and demonstrated that $32 \%$ had body discomfort, $22 \%$ had upper limb discomfort and 19\% had leg discomfort.

Chyuan et al. [4] explored hotel room cleaners' work characteristics and musculoskeletal discomfort. Based on the result, as to musculoskeletal pain, shoulders and neck are the highest $(78.8 \%)$, the following are wrist/finger $(66.2 \%)$ and low back (62.6\%).

Wu et al. [5] studied the risk factors of hotel housekeepers' musculoskeletal situations. The research was based on subjective survey and supported by observation of work and human factor checklist. The findings can help lower housekeepers' occupational musculoskeletal pain. 
Chen et al. [6] probed into highly frequent hotel cleaners' musculoskeletal discomfort. As to musculoskeletal discomfort in hot spring hotels, low back and waist are $61.11 \%$, shoulders are $60.56 \%$ and necks are $53.33 \%$. As to musculoskeletal discomfort in motels, shoulders are $56.8 \%$, low back and waist are $52.8 \%$ and necks are $47.20 \%$.

Regarding correlation between hotel cleaners' musculoskeletal pain and cleaning pose, this study will adopt RULA (Upper Limb Assessment) to explore correlation between hotel cleaners' working pose and force and musculoskeletal plain and through MSDs Checklist, it will find the risk factors of cleaning in hotel industry to serve as reference for medical personnel's diagnosis and treatment of musculoskeletal pain.

\section{MATERIALS AND METHODS}

\subsection{Materials}

This study selected 12 hot spring hotels and 8 motels in Taiwan with intention to receive the survey in 2010. It included 20 highly frequent room cleaners of hotel industry. It recorded the work process of 5 kinds of housekeeping by videos. Finally, it filled them in RULA and MSDs Checklist [7]. Data of discomfort of musculoskeletal pain were provided by IOSH100-H510 of Institute of Labor, Occupational Safety and Health, Ministry of Labor [7] in 2011. 5 kinds of housekeeping includes raising mattress, changing bed sheet and bedspread, cleaning bathtub and hot spring pool and cleaning sink, wall and toilet.

\subsection{Methods}

\subsubsection{Rapid Upper Limb Assessment (RULA)}

By RULA, this study tries to find if hotel cleaners' cleaning pose matches standard human factor engineering. Before using RULA, it recorded cleaners' different cleaning situations and poses by digital video camera and assessed cleaners' force. The researcher calculated and obtained total scores of RULA by checklist and conducted feasible actions. RULA action analysis and calculation principle by McAtamney and Corlett $[8,9]$ :

A. Arm and wrist analysis of cleaning:

1. Step1 (situation of upper arm) + Step2 (situation of forearm) + Step3 (situation of wrist pose) + Step4 (twisting of wrist $)=\mathrm{Step} 5$ (hand and wrist checklist, as shown in Table A)

2. Step5 (hand and wrist checklist)+ Step6(score of muscular capacity) + Step7(weight loading) $=$ Step 8 (scores of hand and wrist)

B. Neck, body and leg analysis of cleaning:

3. Step9 (score of neck pose)+ Step10(score of body pose) + Step11(score of leg) $=$ Step12(checklist of neck, body and leg, as shown in Table B)

4. Step12 (scores of neck, body and leg) + Step13(score of muscular capacity) + Step14(score of leg) $=$ Step 15 (scores of neck, body and leg)

\section{Total score of RULA of cleaning:}

By comparing Step8 (calculation of scores of hand and wrist) and Step15 (scores of neck, body and leg) with Table $\mathbf{C}$, we obtain total scores. Actions are shown in Table $\mathbf{1 .}$

In order to compare hot spring hotel and motel cleaners, this study will adopt Mann-Whitney $U$ method (M-W method) to find two samples and their difference. $\mathrm{M}-\mathrm{W}$ method will be introduced below.

\subsubsection{Mann-Whitney U Method (M-W Method)}

It is similar to T-test with population and it is suitable for test of two groups of samples (hot spring hotel and motel cleaners. Do they have the same median from the same population? Are they from the same population? Does the population of two samples have the same variance?

Through Mann-Whitney U method, it examines the difference of RULA of hot spring hotel and motel cleaners. M$\mathrm{W}$ method action analysis and calculation principle by Mann and Whitney [10], Fay and Proschan [11] .

\subsubsection{MSDs Checklist}

We analyze the result of video recording and adopt MSDs Checklist provided by Institute of Labor, Occupational Safety and Health, Ministry of Labor. Through MSDS Checklist, we calculate the risk factors of Table A, B and $\mathbf{C}$. MSDs Checklist method action analysis and calculation principle by Baron et al. [12], Armstrong et al. [13] and Hagberg et al. [14].

\section{RESULTS}

After data collection and analysis, through RULA, this study will analyze means and action level percentages of two groups of samples (cleaners of hot spring hotels and motels) and correlation and difference between hot spring hotel and motel cleaners' musculoskeletal discomfort and RULA. Means of two groups (hot spring hotel and motel cleaners) are shown in Table 2. RULA action level percentage is shown in Table 3. Correlation between hot spring hotel and motel cleaners' musculoskeletal discomfort and RULA is in Tables 4 and 5. Difference between hot spring hotel and motel cleaners' musculoskeletal discomfort and RULA is in Table 6. Application result of MSDs Checklist on hot spring hotel and motel cleaners' musculoskeletal discomfort is shown from Tables 7-13.

\section{DISCUSSION}

According to result of Table $\mathbf{3}$, after comparing action level difference of hot spring hotel and motel cleaners by RULA, this study realizes that regarding raising mattress and changing bed sheet and bedspread, action level of hot spring hotels is (AL2-3) and action level of motels is (AL2-3). As to cleaning of bathtubs and hot spring pools, action level of hot spring hotels is (AL2-3) and action level of motels is (AL2-3). As to cleaning of sink, action level of hot spring hotels is (AL1-2), and that of motels is (AL1-2). As to cleaning of wall, action level of hot spring hotels is (AL1-2) and action level of motels (AL1-2). Regarding cleaning of toilet, action level of hot spring hotels is (AL2) and that of motels is (AL2). 
Table 1. Action level of working pose of RULA.

\begin{tabular}{|c|c|c|c|c|}
\hline Action Level (AL) & AL1 & AL2 & AL3 & AL4 \\
\hline Total Scores & $\mathbf{1 - 2}$ & $\mathbf{3 - 4}$ & $\mathbf{5 - 6}$ & $\mathbf{7}$ \\
\hline \hline Actions & Action level is acceptable & $\begin{array}{c}\text { In-depth investigation and } \\
\text { improvement if necessary }\end{array}$ & $\begin{array}{c}\text { In-depth investigation and } \\
\text { improvement recently }\end{array}$ & Immediate improvement \\
\hline
\end{tabular}

McAtamney and Corlett $[8,9]$

Table 2. Mean of RULA scores of cleaners' works.

\begin{tabular}{|c|c|c|c|c|c|c|c|c|c|c|}
\hline Items of Work & Hotels & 1 & 2 & 3 & 4 & 5 & 6 & 7 & 8 & $\begin{array}{l}\text { Total } \\
\text { Score }\end{array}$ \\
\hline & & $\begin{array}{c}\text { Score of } \\
\text { Arm }\end{array}$ & $\begin{array}{l}\text { Score of } \\
\text { Forearm }\end{array}$ & $\begin{array}{c}\text { Score of } \\
\text { Wrist }\end{array}$ & $\begin{array}{c}\text { PART } \\
\text { A }\end{array}$ & $\begin{array}{c}\text { Score of } \\
\text { Neck }\end{array}$ & $\begin{array}{c}\text { Score of } \\
\text { Body }\end{array}$ & $\begin{array}{c}\text { Score of } \\
\text { Leg }\end{array}$ & $\begin{array}{c}\text { PART } \\
\text { B }\end{array}$ & $\begin{array}{c}\text { Check- } \\
\text { list } C\end{array}$ \\
\hline $\begin{array}{l}\text { Raising mattress } \\
\text { and changing bed } \\
\text { sheet and bed- } \\
\text { spread }\end{array}$ & Motel & 3.88 & 3 & 3 & 5.58 & 3 & 2.88 & 2 & 4.88 & 5.88 \\
\hline \multirow{2}{*}{$\begin{array}{c}\text { Cleaning bathtub } \\
\text { and hot spring } \\
\text { pool }\end{array}$} & Motel & 2.13 & 3 & 2.13 & 5.13 & 2.13 & 2.13 & 2 & 3.33 & 4.25 \\
\hline & $\begin{array}{c}\text { Hot spring } \\
\text { hotel }\end{array}$ & 2.92 & 3 & 2.92 & 5.92 & 2.92 & 2.92 & 2 & 3.92 & 5.83 \\
\hline \multirow[b]{2}{*}{ Cleaning wall } & Motel & 3.13 & 1.13 & 1.13 & 2.25 & 2.13 & 2 & 1 & 2.13 & 2.13 \\
\hline & $\begin{array}{c}\text { Hot spring } \\
\text { hotel }\end{array}$ & 3.583 & 1.583 & 1.583 & 3.167 & 2.083 & 2 & 1 & 2.083 & 2.667 \\
\hline \multirow[b]{2}{*}{ Cleaning toilet } & Motel & 2.88 & 2 & 2 & 2.88 & 2.88 & 2.88 & 2 & 4.75 & 3.88 \\
\hline & $\begin{array}{l}\text { Hot spring } \\
\text { hotel }\end{array}$ & 2.917 & 2 & 2 & 2.917 & 2.917 & 2.917 & 2 & 4.833 & 3.917 \\
\hline
\end{tabular}

Table 3. RULA action level percentages of hot spring and motel cleaners.

\begin{tabular}{|c|c|c|c|c|c|c|c|c|c|c|}
\hline \multirow{2}{*}{$\begin{array}{l}\text { Action } \\
\text { Level }\end{array}$} & \multicolumn{2}{|c|}{$\begin{array}{c}\text { Raising Mattress and } \\
\text { Changing Bed Sheet and } \\
\text { Bedspread }\end{array}$} & \multicolumn{2}{|c|}{$\begin{array}{c}\text { Cleaning Bathtub and } \\
\text { HOT Spring Pool }\end{array}$} & \multicolumn{2}{|c|}{ Cleaning Sink } & \multicolumn{2}{|c|}{ Cleaning Wall } & \multicolumn{2}{|c|}{ Cleaning Toilet } \\
\hline & $\begin{array}{c}\text { Hot Spring } \\
\text { Hotel } \\
\text { Cleaners }\end{array}$ & $\begin{array}{c}\text { Motel } \\
\text { Cleaners }\end{array}$ & $\begin{array}{c}\text { Hot Spring } \\
\text { Hotel } \\
\text { Cleaners }\end{array}$ & $\begin{array}{c}\text { Motel } \\
\text { Cleaners }\end{array}$ & $\begin{array}{c}\text { Hot Spring } \\
\text { Hotel } \\
\text { Cleaners }\end{array}$ & $\begin{array}{c}\text { Motel } \\
\text { Cleaners }\end{array}$ & $\begin{array}{c}\text { Hot Spring } \\
\text { Hotel } \\
\text { Cleaners }\end{array}$ & $\begin{array}{c}\text { Motel } \\
\text { Cleaners }\end{array}$ & $\begin{array}{c}\text { Hot Spring } \\
\text { Hotel } \\
\text { Cleaners }\end{array}$ & $\begin{array}{c}\text { Motel } \\
\text { Cleaners }\end{array}$ \\
\hline (AL1) & 0 & 0 & 0 & 0 & $91.66 \%$ & $87.5 \%$ & $91.66 \%$ & $87.5 \%$ & 0 & 0 \\
\hline (AL2) & 0 & 0 & $16.67 \%$ & $87.5 \%$ & $8.34 \%$ & $12.5 \%$ & $8.34 \%$ & 12.5 & $100 \%$ & $100 \%$ \\
\hline (AL3) & $100 \%$ & $100 \%$ & $83.33 \%$ & $12.5 \%$ & 0 & 0 & 0 & 0 & 0 & 0 \\
\hline (AL4) & 0 & 0 & 0 & 0 & 0 & 0 & 0 & 0 & 0 & 0 \\
\hline
\end{tabular}


Table 4. Correlation between hot spring hotel cleaners' musculoskeletal discomfort and RULA.

\begin{tabular}{|c|c|c|c|c|c|c|c|c|}
\hline \multirow[b]{2}{*}{ Items of Work } & \multirow[b]{2}{*}{ Parts } & \multirow{2}{*}{ Result } & \multicolumn{2}{|c|}{ Statistics of RULA Scores } & \multirow{2}{*}{$\begin{array}{l}\text { Chi-square } \\
\text { Test Value }\end{array}$} & \multirow{2}{*}{ P Value } & \multirow{2}{*}{$\begin{array}{c}\text { Significance } \\
\text { Level }\end{array}$} & \multirow{2}{*}{$\begin{array}{c}\text { Test result } \\
\begin{array}{l}\text { Significant Dif- } \\
\text { ference }\end{array}\end{array}$} \\
\hline & & & RULA Value $>2$ & RULA Value $>\mathbf{2}$ & & & & \\
\hline \multirow{6}{*}{$\begin{array}{l}\text { Raising mat- } \\
\text { tress and chang- } \\
\text { ing bed sheet } \\
\text { and bedspread }\end{array}$} & \multirow{2}{*}{ Neck } & Comfort & 1 & 4 & \multirow{2}{*}{23.76} & \multirow{2}{*}{0.00} & \multirow{2}{*}{ * } & \multirow{2}{*}{ Yes } \\
\hline & & Discomfort & 6 & 1 & & & & \\
\hline & \multirow{2}{*}{ Body } & Comfort & 0 & 5 & \multirow{2}{*}{15.09} & \multirow{2}{*}{0.00} & \multirow{2}{*}{ * } & \multirow{2}{*}{ Yes } \\
\hline & & Discomfort & 2 & 5 & & & & \\
\hline & \multirow{2}{*}{ Upper arm } & Comfort & 0 & 5 & \multirow{2}{*}{12.75} & \multirow{2}{*}{0.00} & \multirow{2}{*}{$*$} & \multirow{2}{*}{ Yes } \\
\hline & & Discomfort & 1 & 6 & & & & \\
\hline \multirow{8}{*}{$\begin{array}{l}\text { Cleaning bath- } \\
\text { tub and hot } \\
\text { spring pool }\end{array}$} & \multirow{2}{*}{ Neck } & Comfort & 1 & 4 & \multirow{2}{*}{14.62} & \multirow{2}{*}{0.0001} & \multirow{2}{*}{$*$} & \multirow{2}{*}{ Yes } \\
\hline & & Discomfort & 0 & 7 & & & & \\
\hline & \multirow{2}{*}{ Body } & Comfort & 1 & 4 & & & & \\
\hline & & Discomfort & 0 & 7 & 14.62 & 0.0001 & * & Yes \\
\hline & Thom & Comfort & 1 & 4 & & & $*$ & \\
\hline & Upper arm & Discomfort & 0 & 7 & 14.62 & 0.0001 & * & Yes \\
\hline & & Comfort & 1 & 3 & & & & \\
\hline & Wrist & Discomfort & 1 & 7 & 11.55 & 0.0007 & $*$ & Yes \\
\hline & Neck & Comfort & 5 & 0 & 1275 & 00004 & * & Yes \\
\hline C1 & Neck & Discomfort & 6 & 1 & 12.15 & 0.0004 & $*$ & Yes \\
\hline 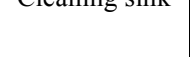 & Unper arm & Comfort & 5 & 0 & 1275 & 00004 & * & Yo \\
\hline & Upper arm & Discomfort & 6 & 1 & 12.15 & 0.0004 & $F^{*}$ & Yes \\
\hline & & Comfort & 4 & 1 & & & & \\
\hline Cleaning wall & Neck & Discomfort & 7 & 0 & 14.62 & 0.0001 & * & Yes \\
\hline & Neck & Comfort & 0 & 5 & 1275 & 00004 & $*$ & Yes \\
\hline & Neck & Discomfort & 1 & 6 & 12.15 & 0.0004 & ${ }^{*}$ & Yes \\
\hline Cleaning toilet & Bodv & Comfort & 1 & 4 & 1462 & 00001 & $*$ & Yes \\
\hline Cleaning tollet & Body & Discomfort & 0 & 7 & 14.02 & 0.0001 & " & Yes \\
\hline & & Comfort & 1 & 4 & & & & \\
\hline & Upper arm & Discomfort & 0 & 7 & 14.62 & 0.0001 & $*$ & Yes \\
\hline
\end{tabular}

Note: $*$ Represents a significant level $<0.05$

Result of Tables $\mathbf{4}$ and $\mathbf{5}$ shows hot spring hotel and motel cleaners' current musculoskeletal discomfort. Based on result of correlation between cleaners' musculoskeletal discomfort and RULA, subjective discomfort of neck, body and upper arm is significantly associated with scores of RULA.

Based on result of Table $\mathbf{6}$, regarding difference between hot spring hotel and motel cleaners, this study adopts Mann-Whitney $U$ method and $T$ test and it demonstrates that as to cleaning bathtubs and hot spring pools, two methods show the difference. As to cleaning of wall, $\mathrm{T}$ test shows difference and Mann-Whitney $U$ method does not. Finally, as to raising mattress and changing bed sheet and bedspread and cleaning sink and toilet, two methods do not show difference.

According to Tables 7 and 13, MSDs Checklist shows low scores of risk factors in Table $\mathbf{C}$. We thus conduct general assessment by total risk factors of Table $\mathbf{B}$ and Table $\mathbf{C}$. Scores of time/risk factors of Work 1 (Table $\mathbf{A}$ ) are calculated by total working hours of Work 1 in Table A /risk factors of Table A. Since Work $3 \sim$ Work 5 do not show any risk factors, we only explore Work 1 and Work 2 in Table A and $\mathbf{B}+\mathbf{C}$. As to Work 1 of Table $\mathbf{A}$ of raising mattress and changing bed sheet and bedspread, this study demonstrates that motels are more dangerous than hot spring hotels. 
Table 5. Correlation between motels cleaners' musculoskeletal discomfort and RULA.

\begin{tabular}{|c|c|c|c|c|c|c|c|c|}
\hline \multirow{2}{*}{ Items of Work } & \multirow{2}{*}{ Parts } & \multirow{2}{*}{ Result } & \multicolumn{2}{|c|}{$\begin{array}{c}\text { Statistics of RULA } \\
\text { Scores }\end{array}$} & \multirow{2}{*}{$\begin{array}{l}\text { Chi-square } \\
\text { Test Value }\end{array}$} & \multirow{2}{*}{ P Value } & \multirow{2}{*}{$\begin{array}{l}\text { Significance } \\
\text { Level }\end{array}$} & \multirow{2}{*}{$\begin{array}{l}\text { Test Result } \\
\begin{array}{l}\text { Significant } \\
\text { Difference }\end{array}\end{array}$} \\
\hline & & & $\begin{array}{c}\text { RULA } \\
\text { Value }>\mathbf{2}\end{array}$ & $\begin{array}{c}\text { RULA } \\
\text { Value }>\mathbf{2}\end{array}$ & & & & \\
\hline \multirow{8}{*}{$\begin{array}{c}\text { Raising mattress and changing } \\
\text { bed sheet and bedspread }\end{array}$} & \multirow{2}{*}{ Neck } & Comfort & 0 & 1 & \multirow{2}{*}{16.75} & \multirow{2}{*}{0.00} & \multirow{2}{*}{$*$} & \multirow{2}{*}{ Yes } \\
\hline & & Discomfort & 1 & 6 & & & & \\
\hline & \multirow{2}{*}{ Body } & Comfort & 1 & 3 & \multirow{2}{*}{16.13} & \multirow{2}{*}{0.00} & \multirow{2}{*}{$*$} & \multirow{2}{*}{ Yes } \\
\hline & & Discomfort & 1 & 3 & & & & \\
\hline & \multirow{2}{*}{ Upper arm } & Comfort & 0 & 1 & \multirow{2}{*}{16.75} & \multirow{2}{*}{0.00} & \multirow[b]{2}{*}{$*$} & \multirow{2}{*}{ Yes } \\
\hline & & Discomfort & 1 & 6 & & & & \\
\hline & \multirow{2}{*}{ Forearm } & Comfort & 0 & 2 & \multirow{2}{*}{17.56} & \multirow[b]{2}{*}{0.00} & \multirow[b]{2}{*}{$*$} & \multirow{2}{*}{ Yes } \\
\hline & & Discomfort & 1 & 5 & & & & \\
\hline \multirow{6}{*}{$\begin{array}{l}\text { Cleaning bathtub and hot } \\
\text { spring pool }\end{array}$} & \multirow{2}{*}{ Neck } & Comfort & 1 & 0 & & & & \\
\hline & & Discomfort & 6 & 1 & 16.75 & 0.00 & * & Yes \\
\hline & & Comfort & 4 & 0 & & & & \\
\hline & Body & Discomfort & 3 & 1 & 20.42 & 0.00 & * & Yes \\
\hline & & Comfort & 1 & 0 & & & & \\
\hline & Upper arm & Discomfort & 6 & 1 & 16.75 & 0.00 & * & Yes \\
\hline & & Comfort & 1 & 0 & & & & \\
\hline & NeCK & Discomfort & 6 & 1 & 10.15 & 0.00 & 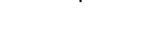 & Yes \\
\hline crearms sims & & Comfort & 1 & 0 & & & & \\
\hline & Upper arm & Discomfort & 6 & 1 & 16.15 & 0.00 & $*$ & Yes \\
\hline & & Comfort & 1 & 0 & & & & \\
\hline Cleaning wall & Neck & Discomfort & 6 & 1 & 16.75 & 0.00 & * & Yes \\
\hline & N 1 & Comfort & 0 & 1 & 1675 & 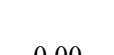 & * & Yer \\
\hline & & Discomfort & 1 & 6 & & 0.00 & & \\
\hline & & Comfort & 1 & 3 & & & & \\
\hline Cleaning toilet & Body & Discomfort & 0 & 4 & 20.42 & 0.00 & 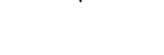 & Yes \\
\hline & & Comfort & 0 & 1 & & & & \\
\hline & Upper arm & Discomfort & 1 & 6 & 16.75 & 0.00 & * & Yes \\
\hline
\end{tabular}

Note: *Represents a significant level $<0.05$

Table 6. Difference between hot spring hotel and motel cleaners' cleaning of bathtubs and hot spring pools and RULA.

\begin{tabular}{|c|c|c|c|c|c|c|}
\hline Items & T Test & P Value & Significance & M-W Method & P Value & Significance \\
\hline Score of upper arm & -5.498 & 0.00 & Yes & 10 & 0.002 & Yes \\
\hline Score of wrist & -5.270 & 0.00 & Yes & 9 & 0.003 & Yes \\
\hline Score of neck & -5.498 & 0.00 & Yes & 10 & 0.002 & Yes \\
\hline Total score of RULA & -5.270 & 0.00 & Yes & 9 & 0.003 & Yes \\
\hline
\end{tabular}


Table 7. Basic information analysis of hotel cleaners.

\begin{tabular}{|c|c|c|c|}
\hline \multicolumn{2}{|c|}{ Category } & Hot Spring Hotel & Motel \\
\hline \multicolumn{2}{|c|}{ Number of Employees } & 12 & 8 \\
\hline \multirow{6}{*}{$\begin{array}{l}\text { Working hours } \\
\text { (hours) }\end{array}$} & Work 1 & 3.98 hours & 3.125 hours \\
\hline & Work 2 & 2.42 hours & 2.5 hours \\
\hline & Work 3 & 1.32 hours & 1.875 hours \\
\hline & Work 4 & 1.06 hours & 1.25 hours \\
\hline & Work 5 & 1.21 hours & 1.25 hours \\
\hline & Total working hours & 10 hours & 10 hours \\
\hline
\end{tabular}

Table 8. Table A analysis of hotel cleaners' cleaning.

\begin{tabular}{|c|c|c|c|}
\hline \multicolumn{2}{|c|}{ Table A } & Hot Spring Hotel & Motel \\
\hline \multicolumn{3}{|c|}{ Number of Employees } & $\mathbf{1 2}$ \\
\hline \multirow{3}{*}{ Scores } & Work 1 & 7.50 & 9 \\
\cline { 2 - 4 } & Work 2 & 5.67 & 4 \\
\cline { 2 - 4 } & Work 3 & 0 & 0 \\
\cline { 2 - 4 } & Work 4 & 0 & 0 \\
\cline { 2 - 4 } & Work 5 & 0 & 0 \\
\cline { 2 - 4 } & Average & 13.17 & 13 \\
\hline
\end{tabular}

Table 9. Table B analysis of hotel cleaners' cleaning.

\begin{tabular}{|c|c|c|c|}
\hline \multicolumn{2}{|c|}{ Table B } & Hot Spring Hotel & Motel \\
\hline \multicolumn{3}{|c|}{ Number of Employees } & $\mathbf{1 2}$ \\
\hline \hline \multirow{3}{*}{ Scores } & Work 1 & 6.33 & 7 \\
\cline { 2 - 5 } & Work 2 & 3.33 & 5 \\
\cline { 2 - 4 } & Work 3 & 0.00 & 0 \\
\cline { 2 - 4 } & Work 4 & 0.00 & 0 \\
\cline { 2 - 4 } & Work 5 & 0.00 & 0 \\
\cline { 2 - 4 } & Average & 9.67 & 12 \\
\hline
\end{tabular}

Table 10. Table $\mathbf{C}$ analysis of hotel cleaners' cleaning.

\begin{tabular}{|c|c|c|c|}
\hline \multicolumn{2}{|c|}{ Table C } & Hot Spring Hotel & Motel \\
\hline \multicolumn{3}{|c|}{ Number of Employees } & $\mathbf{1 2}$ \\
\hline \hline \multirow{5}{*}{ Scores } & Work 1 & 2.67 & 2 \\
\cline { 2 - 5 } & Work 2 & 0 & 0 \\
\cline { 2 - 4 } & Work 3 & 0 & 0 \\
\cline { 2 - 4 } & Work 4 & 0 & 0 \\
\cline { 2 - 4 } & Work 5 & 0 & 0 \\
\cline { 2 - 4 } & Average & 2.67 & 2 \\
\hline
\end{tabular}


Table 11. Total average of Work 1 of Table $B+C$.

\begin{tabular}{|c|c|c|c|}
\hline \multicolumn{2}{|c|}{ Total Average of Work 1 of Table $B+C$} & Mean of Category A & Mean of B Category \\
\hline \multicolumn{2}{|c|}{ Number of Employees } & 12 & 8 \\
\hline \multirow{3}{*}{ Scores } & Table B Work 1 & 7 & 7 \\
\hline & Table C Work 1 & 2 & 2 \\
\hline & Total average of Work 1 of Table $\mathrm{B}+\mathrm{C}$ & 9 & 9 \\
\hline
\end{tabular}

Table 12. Total average of Work 2 of Table $B+C$.

\begin{tabular}{|c|c|c|c|}
\hline \multicolumn{2}{|c|}{ Total Average of Work 2 of Table B+C } & Mean of Category A & Mean of B Category \\
\hline \multirow[t]{2}{*}{ Scores } & Table C Work 2 & 0 & 0 \\
\hline & Total average of Work 2 of Table $\mathrm{B}+\mathrm{C}$ & 3 & 5 \\
\hline
\end{tabular}

Table 13. Total average of Work 1 and 2 in Table A, B and C.

\begin{tabular}{|c|c|c|}
\hline Scores of time/risk factors & Mean of Category A & Mean of B Category \\
\hline Number of employees & $\mathbf{1 2}$ & $\mathbf{8}$ \\
\hline \hline Work 1 (Table A) & $53.16 \%$ & $62.5 \%$ \\
\hline Work 2 (Table A) & $42.29 \%$ & $34.72 \%$ \\
\hline Work 1 (Table B +Table C) & $46.54 \%$ & $50 \%$ \\
\hline Work 2 (Table B +Table C) & $73.56 \%$ & \\
\hline
\end{tabular}

As to Work 2 of Table A of cleaning bathtub and hot spring, hot spring hotels are more dangerous than motels.

\section{CONCLUSION}

Based on analysis of RULA, for motels and hot spring hotels, the work which requires in-depth investigation and improvement is raising mattress and changing bed sheet and bedspread. Action level is (AL2-AL3). As to cleaning bathtub and hot spring pool, action level of motels and hot spring hotels is (AL2-AL3) and it should be further studied. According to correlation between hotel cleaners' musculoskeletal discomfort and RULA, subjective discomfort of neck, body and upper arm is significantly associated with scores of RULA. By comparing hot spring hotel and motel cleaners, we realize that as to cleaning hot spring pool and bathtub, scores of poses of RULA are significantly different. It might be due to different designs of hot spring pool of hot spring hotels hot spring pool and Jacuzzi of motels. The cleaners tend to have excessive force and bad poses and it cause musculoskeletal discomfort. We suggest improving bad poses and excessive force by long brushes.

Based on analysis of MSDs checklist, as to Work 1 of Table A of raising mattress and changing bed sheet and bedspread, motels are more dangerous than hot spring hotels. Regarding Work 2 of Table A of cleaning bathtub and hot spring pool, hot spring hotels are more dangerous than motels. Based on on-site visit, in highly frequent hotel industry, 2 or 3 sections are arranged for cleaning. As to arrangement of cleaners, each section includes 4 5 cleaners. On average, each cleaner cleans 20 30 rooms, and the workload is higher than common hotels.

This study suggests that when cleaners' salaries are based on cases, long brushes can be used to clean hot spring pool and Jacuzzi. It will avoid the musculoskeletal discomfort of low back and waist. When cleaners receive monthly wages, we suggest that besides long brushes which avoid musculoskeletal discomfort of low back and waist, rest hours or manpower can be increased. As to low back and waist, future researchers can adopt KIM analysis. Findings of this study can serve as reference for improvement of work process in hotels or medical personnel's diagnosis and treatment.

\section{CONFLICT OF INTEREST}

The authors confirm that this article content has no conflict of interest.

\section{ACKNOWLEDGEMENTS}

This study was financially sponsored by the Institute of Labor, Occupational Safety and Health, Ministry of Labor under Grant, Taiwan, ROC. (No. IOSH100-H510) 


\section{REFERENCES}

[1] N. Krause, T. Scherzer, and R. Rugulies, "Physical workload, work intensification, and prevalence of pain in low wage workers: results from a participatory research project with hotel room cleaners in Las Vegas," Am. J. Ind. Med, vol. 48, no. 5, pp. 326$337,2005$.

[2] NIOSH, "How hotel work is hurting housekeepers", 2006. [www.hotelworkersrising.org/pdf/Injury Paper.pdf]

[3] E. Frumin, J. Moriarty, P. Vossenas, J. Halpin, P. Orris, N. Krause, and L. Punnett, "Workload-related musculoskeletal disorders among hotel housekeepers: employer records reveal a growing national problem,” 2006. [www.hotelworkersrising.org/pdf/hskpr_ analysis0406.pdf]

[4] J.Y. Chyuan, W. S. Yen, C.Y. Li, and C.Y. Chen, "A crosssectional study of musculoskeletal discomfort with hotel guestroom attendant work content," J. Occup. Safe. Health, vol. 15, pp. 232242, 2007.

[5] S. P. Wu, and C. P. Chiu, "Ergonomics study for musculoskeletal injuries of hotel housekeeping worker," J. Occup. Safe. Health, vol. 15, pp. 179-190, 2007.

[6] C.Y. Chen, Y. C. Chen, J. Y. Kuo, L. W. Liu, and C. T. Shen, "The musculoskeletal disorders research of high frequency restaurant cleaners", J. Occup. Safe. Health, vol. 20, pp. 478-484, 2012.

[7] Institute of Labor, Occupational Safety And Health, Ministry of Labor. [http://www.iosh.gov.tw] 2015.
[8] L. McAtamney, and E.N. Corlett, "Rapid Upper limb assessment (RULA) in Stanton", Handbook of human factors and ergonomics methods, Chapter 7, Boca Raton, FL, pp. 1-11, 2004.

[9] L. McAtamney, and E.N. Corlett "Based on RULA: a survey method for the investigation of work-related upper limb disorders," Appl. Ergon, vol. 24, no 2, pp.91-99, 1993.

[10] H. B. Mann, and D. R. Whitney, "On a test of whether one of two random variables is stochastically larger than the other," Ann. Math. Stat, vol. 18, no. 1, pp. 50-60, 1947.

[11] M. P Fay, and M. A. Proschan, “Wilcoxon-Mann-Whitney or ttest? On assumptions for hypothesis tests and multiple interpretations of decision rules," Stat. Surv, vol. 4, pp. 1-39, 2010.

[12] S. Baron, T. Hales, and L. Fine, "Evaluation of a questionnaire to assess the prevalence of work-related musculoskeletal disorders," International Scientific Conference on Prevention of Work-related Musculoskeletal Disorders-PREMUS, pp. 39-41, 1992.

[13] T.J. Armstrong, P. Buckle, L.J. Fine, M. Hagberg, B. Jonsson, A. Kilbom, IAA. Kuorinka, B.A Silverstein, G Sjogaard, and J. Viikari, "ERA: A conceptual model for work-related neck and upperlimb musculoskeletal disorders," Scand. J. Work. Env. Health, vol. 19, pp. 73-84, 1993.

[14] M. Hagberg, B. Silverstein, R. Wells, M. Smith, H. Hendrick, P. Cararyon, and M. Perusse: Identification, measurement and evaluation of risk, Chapter 4, pp. 139-212. In: F. Kuorinka (ed): WorkRelated Musculoskeletal Disorders-A Manual for Prevention. Taylor \& Francis, London, 1995.

(C) Kuo et al.; Licensee Bentham Open.

This is an open access article licensed under the terms of the Creative Commons Attribution Non-Commercial License (http://creativecommons.org/licenses/by-nc/3.0/) which permits unrestricted, non-commercial use, distribution and reproduction in any medium, provided the work is properly cited. 